\title{
Solid-Liquid Reactions in the System $\mathrm{Si}_{3} \mathrm{~N}_{4}-\beta$-SiAlON- $\mathrm{Y}_{3} \mathrm{Al}_{5} \mathrm{O}_{12}$
}

\author{
Michele Wisnudel and Tseng-Ying Tien*
}

Materials Science and Engincering, The University of Michigan, Ann Arbor, Michigan 48109

\begin{abstract}
Solid-liquid equilibria in the system $\mathrm{Si}, \mathrm{Al}, \mathrm{Y} / \mathrm{N}, \mathrm{O}$ were determined for the compatibility triangle bounded by the $\beta$-SiAION solid-solution line and the compound $\mathrm{Y}_{3} \mathrm{AI}_{5} \mathrm{O}_{12}$. $X$-ray diffraction was used to determine the crystalline phases present in the equilibrated, rapidly cooled specimens. The liquid phase was quantified with volume fraction measurements performed on scanning electron micrographs. The solid-liquid tie lines at $1650^{\circ}$ and $1750^{\circ} \mathrm{C}$ were established from lattice parameters of the $\beta$-SiAION phase and from the amount of liquid phase in equilibrium with the crystalline solid. The liquid phase was crystallized to verify the location of the starting composition.
\end{abstract}

\section{Introduction}

$\mathbf{S}^{\mathrm{n}}$ LICON NITRIDE and SiAION, silicon nitride with aluminum and oxygen replacing the silicon and nitrogen,' are materials currently under investigation for their application as high-temperature ceramics. The covalent bond between silicon and nitrogen provides excellent material properties, including high hardness and strength, but unfortunately prohibits densification of powder compacts. Oxide sintering agents such as $\mathrm{Y}_{2} \mathrm{O}_{3}$, $\mathrm{Al}_{2} \mathrm{O}_{3}$, and $\mathrm{MgO}$ ajd the densification process at high sintering temperatures by forming a eutectic liquid with the silicon nitride, allowing liquid phase sintering to occur. However, this liquid phase forms a glassy grain boundary phase upon cooling and lowers the strength of the ceramic, especially at higher temperatures. Understanding the phase equilibria (or the solidliquid equilibria) of silicon nitride-metal oxide systems provides insight into the densification processes of nitrogen ceramics and allows for the reproducible characterization of the properties of these ceramics. Silicon nitride-metal oxide systems are represented as reciprocal salt systems expressed in terms of the constituent elements, e.g., Si,M/N,O where $M$ is a metal. $^{2}$

Phase equilibria have been studied extensively in silicon nitride-metal oxide systems. Subsolidus phase equilibria have been investigated in the systems $\mathrm{Si}, \mathrm{Al} / \mathrm{N}, \mathrm{O}^{3}$ and $\mathrm{Si}, \mathrm{Y} / \mathrm{N}, \mathrm{O}^{4}$. Solid-liquid equilibrium has been studied at $1750^{\circ} \mathrm{C}$ in the $\mathrm{Si}, \mathrm{Al} / \mathrm{N}, \mathrm{O}$ system. ${ }^{5}$ Combining the systems $\mathrm{Si}, \mathrm{Al} / \mathrm{N}, \mathrm{O}$ and $\mathrm{Si}, \mathrm{Y} / \mathrm{N}, \mathrm{O}$ gives the quasiquaternary system $\mathrm{Si}, \mathrm{Al}, \mathrm{Y} / \mathrm{N}, \mathrm{O}$. Studying the phase equilibria in this system is essential to understanding the effects of adding both $\mathrm{Y}_{2} \mathrm{O}_{3}$ and $\mathrm{AI}_{2} \mathrm{O}_{3}$ as sintering aids.

The system $\mathrm{Si}, \mathrm{Al}, \mathrm{Y} / \mathrm{N}, \mathrm{O}$ is composed of 68 compatibility tetrahedra, but the most promising region for high-temperature ceramics is bounded by the $\mathrm{Si}_{3} \mathrm{~N}_{4}-\mathrm{Al}_{2} \mathrm{O}_{3}$ :AIN-YAG- $\mathrm{Y}_{2} \mathrm{Si}_{2} \mathrm{O}_{7}$ compatibility tetrahedron. ${ }^{6} \mathrm{YAG}$ refers to the yttrium aluminum garnet, $3 \mathrm{Y}_{2} \mathrm{O}_{3} \cdot 5 \mathrm{Al}_{2} \mathrm{O}_{3}$. Hohnke and Tien ${ }^{7}$ studied the solid-liquid reactions in this region. They found a two-phase field over the entire $\mathrm{Si}_{3} \mathrm{~N}_{4}-\beta_{60}-\mathrm{YAG}$ plane at $1550^{\circ} \mathrm{C}$, with the

P. F. Becher-contributing editor

\footnotetext{
Manuscript No. 194000. Reccived January 24, 1994; approved May 31, 1994 Supported by the Ceramic Technology Project, DOE Office of Transportation Technologies under Contract No. DE-AC05-84OR21400 with Martin Marietta Energy

nologies

*Member, American Ceramic Society.
}

liquid first forming along the $\mathrm{YAG}-\beta_{60}$ join. $\beta_{60}$ refers to the 60 equivalent percent $\mathrm{Al}-\mathrm{O}$ substituted $\beta$-silicon nitride with the formula $\mathrm{Si}_{6-x} \mathrm{Al}_{x} \mathrm{O}_{x} \mathrm{~N}_{8-x}$ with $x=4$. This system was later studied by Spacie et al. ${ }^{8}$ Their results differed from those of Hohnke and Tien in that the liquid was first found on the $\beta$-YAG plane at $1650^{\circ} \mathrm{C}$, and the liquid phase extended from the $\mathrm{Si}_{3} \mathrm{~N}_{4}-\mathrm{YAG}$ join. The focus of this research is to clarify the solid-liquid reactions in the $\mathrm{Si}_{3} \mathrm{~N}_{4}-\beta_{60}-\mathrm{YAG}$ compatibility triangle at temperatures above $1550^{\circ} \mathrm{C}$. Solid-liquid tie lines were established at $1650^{\circ}$ and $1750^{\circ} \mathrm{C}$ from lattice parameters of the $\beta$-phase and from the amount of liquid phase in equilibrium with the crystalline solid. X-ray diffraction was used for phase identification, and scanning electron micrographs from a polished surface were used to quantify the amount of liquid phase present in the samples. The liquid phase was crystallized to verify the location of the starting composition.

\section{Experimental Procedure}

\section{(1) Sample Preparation}

Four compositions were prepared from the starting powders $\alpha-\mathrm{Si}_{3} \mathrm{~N}_{4}$ (Hermann C. Starck LC12), AIN (Hermann C. Starck Grade A), $\alpha-\mathrm{Al}_{2} \mathrm{O}_{3}$, and $\mathrm{Y}_{2} \mathrm{O}_{3}$. Compositions studied are given in Table I. Oxygen content of the silicon nitride $(2.0 \%)$ and aluminum nitride $(1.3 \%)$ powders were taken into account in computing the compositions. These compositions were mixed by hand with an agate mortar and pestle with isopropyl alcohol. Dried mixtures were pressed into pellets and isostatically pressed under a pressure of $300 \mathrm{MPa}$. All of the specimens were put in BN-packed graphite crucibles and fired in a graphiteresistant furnace under static nitrogen of 1 atm pressure. The samples were heat treated at $1650^{\circ}$ and $1750^{\circ} \mathrm{C}$. Samples were soaked for $24 \mathrm{~h}$ at a temperature sufficient to ensure equilibrium. Specimens used for phase analysis had less than $2 \%$ weight loss after firing at $1650^{\circ} \mathrm{C}$ and $3 \%$ weight loss after firing at $1750^{\circ} \mathrm{C}$.

\section{(2) Phase Identification}

Specimens were analyzed using X-ray diffraction with $\mathrm{Cu} K \alpha$. All heat-treated samples contained only two phases, $\beta$-SiAlON and liquid. The glassy phase was apparent from the $X$-ray data because of increased background intensity. $\beta-S i A I O N$ has a hexagonal structure and it was identified with $\mathrm{X}$-ray data. Lattice parameter calculations were performed to determine the amount of $\mathrm{Al}$ in the $\beta$-SiAlON phase. A computer program was utilized to carry out these calculations. ${ }^{9}$ The $\beta$-SiAlON peak angles were input with their corresponding planes so that the lattice parameters, $a$ and $c$ values of the $\beta$-SiAION hexagonal unit cell, could be given as output. The $\beta$-SiAION peaks used for identification include [200], [210], [300], [310], [301], [221], [311], and [320]. The generated lattice parameters were compared with $\beta$-silicon nitride and $\beta_{60}$ lattice parameters to determine $x$ in the SiAlON formula, $\mathrm{Si}_{6-x} \mathrm{Al}_{x} \mathrm{O}_{x} \mathrm{~N}_{8-x}$. It has been shown that the lattice parameters of $\beta$-SiAION vary linearly with $x .^{10}$ The $x$ values were converted to weight percent $\mathrm{AlN}: \mathrm{Al}_{2} \mathrm{O}_{3}$ and are plotted on the $\mathrm{Si}_{3} \mathrm{~N}_{4}-\beta_{60}-$ YAG compatibility triangle. For example, $\beta_{601}$ can be expressed either with the formula $(x=4) \mathrm{Si}_{2} \mathrm{Al}_{4} \mathrm{O}_{4} \mathrm{~N}_{4}$ or as a combination of the starting materials required to produce this 
Table I. Sample Compositions with Relative Amounts of Starting Powders

\begin{tabular}{cccccc}
\hline Sample ID & Compositions $(w t \%)$ & $\mathrm{Si}_{3} \mathrm{~N}_{4}$ & $\mathrm{Y}_{2} \mathrm{O}_{3}$ & $\mathrm{Al}_{2} \mathrm{O}_{3}$ & \multicolumn{1}{c}{ AIN } \\
\hline $\mathrm{SY}-19$ & $90 \beta_{10} / 10 \mathrm{YAG}$ & 79.938 & 5.706 & 7.948 & 5.769 \\
$\mathrm{SY}-20$ & $90 \beta_{23} / 10 \mathrm{YAG}$ & 66.522 & 5.706 & 17.973 & 9.269 \\
$\mathrm{SY}-21$ & $90 \beta_{36} / 10 \mathrm{YAG}$ & 53.106 & 5.706 & 28.002 & 12.764 \\
$\mathrm{SY}-22$ & $90 \beta_{49} / 10 \mathrm{YAG}$ & 39.690 & 5.706 & 38.038 & 16.25 \\
\hline
\end{tabular}

formula. $\beta_{60}$ can be written as $\frac{2}{3} \mathrm{Si}_{3} \mathrm{~N}_{4}+\frac{4}{3} \mathrm{AlN}: \mathrm{Al}_{2} \mathrm{O}_{3}$, and the weight percent of $\mathrm{AIN}: \mathrm{Al}_{2} \mathrm{O}_{3}$ can be calculated. $\beta_{60}$ contains $67.1 \mathrm{wt} \% \mathrm{AIN}: \mathrm{Al}_{2} \mathrm{O}_{3}$. Similarly the $\mathrm{AIN}: \mathrm{Al}_{2} \mathrm{O}_{3}$ weight percents of the individual $\beta$-phases can be calculated. Once the weight percents of $\mathrm{AIN}: \mathrm{Al}_{2} \mathrm{O}_{3}$ are known, lines can be drawn connecting the position of the starting composition on the compatibility triangle to the weight percent of $\mathrm{AIN}: \mathrm{Al}_{2} \mathrm{O}_{3}$ on the $\mathrm{Si}_{3} \mathrm{~N}_{4}-$ $\mathrm{Si}_{2} \mathrm{Al}_{4} \mathrm{O}_{4} \mathrm{~N}_{4}$ join. The lattice parameters of specimens after firing were determined and compared with the standard values. The results are given in Table II.

\section{(3) Liquid Phase Quantification}

Samples were polished for scanning electron microscopy studies. Two phases were apparent from SEM micrographs: silicon nitride grains and the liquid phase surrounding the grains. The volume fraction of liquid phase present in the specimens was quantified by measuring the volume of liquid phase apparent from the SEM micrographs. The point count method used to calculate the volume fraction of this liquid phase is described in Underwood." Micrographs of the same magnification $(10 \mathrm{k})$ and same area were used for the measurements. A grid was placed over the micrographs and the number of grid intersections which covered the liquid phase area were totaled. This number was divided by the total number of grid points to calculate the liquid phase volume fraction. The number of grid points used to calculate the volume fractions was deciphered in order to establish a $10 \%$ confidence interval.

The liquid phase volume fractions were converted to weight fractions using the following equation:

$$
X_{\mathrm{w}}=\frac{X_{\mathrm{v} l} \rho_{\mathrm{l}}}{X_{\mathrm{vl}} \rho_{1} 1+X_{\mathrm{v} \beta} \rho_{\beta}}
$$

$X_{\mathrm{W}}$ is the weight fraction of the liquid phase, and $X_{\mathrm{v}}$ and $X_{\mathrm{v} \beta}$ are the volume fractions of liquid and $\beta$ phases. $\rho_{1}$ and $\rho_{\beta}$ are the densities of the liquid and $\beta$-phases. The density of the liquid phase was estimated using $\mathrm{Y}-\mathrm{Si}-\mathrm{Al}-\mathrm{O}-\mathrm{N}$ glass density results published by Messier. ${ }^{2}$

The value of $3.92 \mathrm{~g} / \mathrm{cm}^{3}$ was used for the glass density. The density of each $\beta$-SiAlON was calculated using the equation

$$
\rho=\frac{280.5666+0.8887 x}{\left[(7.6059+0.0273 x)^{2}(2.9108+0.0244 x)\right](0.866)} \frac{\mathrm{g}}{\mathrm{cm}^{3}}
$$

The variable $x$ is the same as that seen in the $\beta$-SiAION formula, $\mathrm{Si}_{6-x} \mathrm{Al}_{x} \mathrm{O}_{x} \mathrm{~N}_{8} \ldots$. Once the weight fraction of the liquid phase is known, the liquidus location can be determined using

\begin{tabular}{|c|c|c|c|c|}
\hline Sample ID & $a(\AA)$ & $c(\AA)$ & $x$ & $\begin{array}{l}\text { Weight percent } \\
\text { AIN: } \mathrm{Al}_{2} \mathrm{O}_{3}\end{array}$ \\
\hline \multicolumn{5}{|l|}{$1650^{\circ} \mathrm{C}$} \\
\hline SY-19 & 7.617 & 2.920 & 0.55 & 0.093 \\
\hline SY -20 & 7.645 & 2.946 & 1.55 & 0.262 \\
\hline SY-21 & 7.669 & 2.967 & 2.50 & 0.421 \\
\hline SY -22 & 7.695 & 2.990 & 3.40 & 0.571 \\
\hline \multicolumn{5}{|l|}{$1750^{\circ} \mathrm{C}$} \\
\hline SY-19 & 7.624 & 2.926 & 0.80 & 0.135 \\
\hline$S Y-20$ & 7.652 & 2.953 & 1.85 & 0.312 \\
\hline$S Y-21$ & 7.673 & 2.970 & 2.60 & 0.438 \\
\hline SY -22 & 7.696 & 2.990 & 3.40 & 0.572 \\
\hline
\end{tabular}

Table II. $\quad \beta$-SiAION Lattice Parameters after Sintering the lever rule. The results of these measurements are given in Table III.

\section{(4) Liquid Phase Crystallization}

Heat-treated samples were annealed in the graphite-resistant furnace under static nitrogen of 1 atm pressure. Samples were held at $1400^{\circ} \mathrm{C}$ for $24 \mathrm{~h}$, since it has been shown that nearly complete crystallization of the liquid phase can occur at this temperature and time duration. X-ray analysis was performed on samples to determine phases. Two phases, $\beta$-phase and YAG, were apparent in the samples. Lattice parameter calculations were performed on the $\beta$-phases and were compared to results from nonannealed samples. It is apparent that there was a compositional change during firing. The lattice parameters and the $x$-values of the solid solutions are given in Table IV.

\section{Results and Discussion}

Samples were sintered at $1650^{\circ}$ and $1750^{\circ} \mathrm{C}$, and phases were analyzed using $\mathrm{X}$-ray diffraction. The equilibrium and nonequilibrium phases were detected; two types of nonequilibrium phases were identified. The first type of nonequilibrium phase is one that occurs off the plane of the $\mathrm{Si}_{3} \mathrm{~N}_{4}-\beta$-SiAlON-YAG compatibility plane. These types of phases include yttrium silicates and SiAION polytypoids. ${ }^{13}$ These phases occur primarily because of the difficulty in composition control and processing. The second type of nonequilibrium phase detected is YAG. Samples sintered at $1650^{\circ} \mathrm{C}$. contained crystalline $\mathrm{YAG}$ when the sintering times were short and the cooling rates were slow. However, samples held at both $1650^{\circ}$ and $1750^{\circ} \mathrm{C}$ for $24 \mathrm{~h}$ contained only $\beta$-SiAlON and a liquid phase. Equilibrium was

Table III. Results of Liquid Phase Quantification

\begin{tabular}{cccc}
\hline Sample ID & $\begin{array}{c}\beta \text {-SiAlON } \\
\text { density }\left(\mathrm{g} / \mathrm{cm}^{3}\right)\end{array}$ & $\begin{array}{c}\text { Volume fraction, } \\
\text { liquid phase }\end{array}$ & $\begin{array}{c}\text { Weight fraction, } \\
\text { liquid phase }\end{array}$ \\
\hline $1650^{\circ} \mathrm{C}$ & & & \\
SY-19 & 3.173 & 0.127 & 0.152 \\
SY-20 & 3.134 & 0.134 & 0.162 \\
SY-21 & 3.098 & 0.135 & 0.165 \\
SY-22 & 3.064 & 0.136 & 0.167 \\
$1750^{\circ} \mathrm{C}$ & & & \\
SY-19 & 3.163 & 0.121 & 0.145 \\
SY-20 & 3.122 & 0.136 & 0.165 \\
SY-21 & 3.094 & 0.139 & 0.169 \\
SY-22 & 3.064 & 0.142 & 0.175 \\
\hline
\end{tabular}

Table IV. $\quad \beta$-SiAION Lattice Parameters after Crystallization

\begin{tabular}{ccccc}
\hline Sample ID & $a(\AA)$ & $c(\AA)$ & $x$ & $\begin{array}{c}\text { Weight percent } \\
\text { AIN: } \mathrm{Al}_{2} \mathrm{O}_{3}\end{array}$ \\
\hline $1650^{\circ} \mathrm{C}$ & & & & \\
$\mathrm{SY}-19$ & 7.624 & 2.930 & 0.80 & 0.135 \\
$\mathrm{SY}-20$ & 7.651 & 2.951 & 1.75 & 0.294 \\
$\mathrm{SY}-21$ & 7.673 & 2.972 & 2.60 & 0.438 \\
$\mathrm{SY}-22$ & 7.695 & 2.991 & 3.45 & 0.579 \\
$1750^{\circ} \mathrm{C}$ & & & & \\
$\mathrm{SY}-19$ & 7.629 & 2.933 & 1.05 & 0.178 \\
$\mathrm{SY}-20$ & 7.652 & 2.952 & 1.85 & 0.312 \\
$\mathrm{SY}-21$ & 7.674 & 2.972 & 2.65 & 0.446 \\
$\mathrm{SY}-22$ & 7.697 & 2.991 & 3.50 & 0.587 \\
\hline
\end{tabular}


assumed to occur when phases remained consistent through extended sintering times. The equilibrium phases are $\beta-S i A l O N$ and liquid. Only those samples considered to be at equilibrium were further analyzed.

Lattice parameter measurements were calculated on those samples which contained $\beta-S i A I O N$ and a liquid phase. The lattice parameter values of the individual $\beta$-phases were compared to $\mathrm{Si}_{3} \mathrm{~N}_{4}$ and $\beta_{61}$ lattice parameters. The amount of solid solution was determined for each composition at $1650^{\circ}$ and $1750^{\circ} \mathrm{C}$, and these data are summarized in Table II. This information can also be visualized on the $\mathrm{Si}_{3} \mathrm{~N}_{4}-\beta-\mathrm{SiAlON}-\mathrm{YAG}$ compatibility triangles. Diagrams were drawn with weight percent $\mathrm{AlN}: \mathrm{Al}_{2} \mathrm{O}_{3}$ as the scale along the $\mathrm{Si}_{3} \mathrm{~N}_{4}-\beta_{60}$ join. Lines connect the position of the prepared composition with the corresponding amount of solid solution along the $\mathrm{Si}_{3} \mathrm{~N}_{4}-\beta_{60}$ join. It is important to note the shift in weight percent of $\mathrm{AlN}: \mathrm{Al}_{2} \mathrm{O}_{3}$, or the increasing $\mathrm{Al}$ solubility in the $\mathrm{Si}_{3} \mathrm{~N}_{4}$, with increasing temperature.

Scanning electron microscopy was performed on samples polished to $0.1 \mathrm{~mm}$. Liquid volume fractions were calculated on the micrographs using the point count method. Densities were calculated for the $\beta$-phases, and the liquid volume fractions were converted to weight fractions. The results are listed in Table III. The liquid weight fractions are approximately $16 \%$ for both the samples sintered at $1650^{\circ}$ and $1750^{\circ} \mathrm{C}$. In Fig. 1, the tie lines are extended to include the liquid phase information.

It appears from the diagrams that the liquidus region extends from the $\mathrm{Si}_{3} \mathrm{~N}_{4}-\mathrm{YAG}$ join; however, these tie lines were drawn connecting the weight percent $\mathrm{AlN}: \mathrm{Al}_{2} \mathrm{O}_{3}$ of each $\beta$-phase with
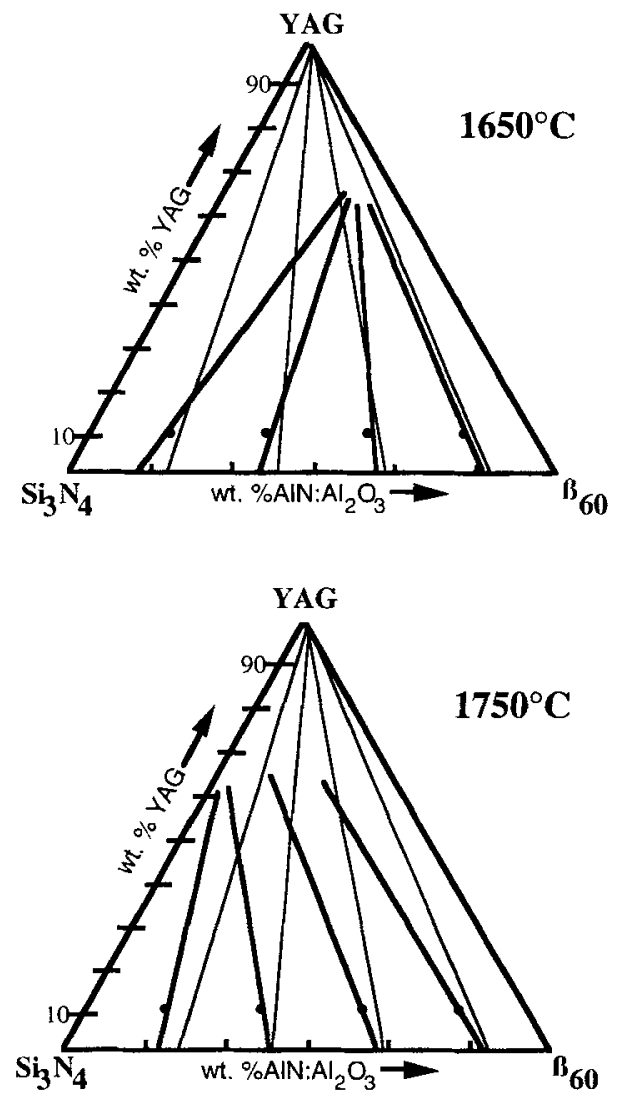

Fig. 1. The dots represent the original prepared starting compositions. The thick lines represent the tie lines which were drawn after the first heat treatment. These tie lines connect the weight percent $\mathrm{AlN}: \mathrm{Al}_{2} \mathrm{O}_{3}$ of each $\beta$-phase to the starting composition. The length of the tie line was determined using the lever rule, since relative amounts of liquid and $\beta$-phases were determined. The thin lines represent the tie lines which were drawn after the samples were annealed. These tie lines connect the weight percent $\mathrm{AIN}: \mathrm{Al}_{2} \mathrm{O}_{3}$ of each $\beta$-phase to $\mathrm{YAG}$, the apex of the compatibility triangle. These diagrams show that the starting compositions are shifting during heat treatment, especially at $1750^{\circ} \mathrm{C}$. the starting composition of each sample. The starting compositions may shift during heat treatment, so a second heat treatment was performed to verify the starting composition location.

Samples were annealed to crystallize the liquid phase. Two phases were present in these samples, $\beta$-phase and YAG. Lattice parameter measurements were performed to determine the amount of $\mathrm{Al}$ in the $\beta$-phase. These results are tabulated in Table IV. Tie lines were drawn connecting the amount of $\mathrm{Al}$ in solid solution along the $\mathrm{Si}_{3} \mathrm{~N}_{4}-\beta_{60}$ join to $\mathrm{YAG}$, the apex of the $\mathrm{Si}_{3} \mathrm{~N}_{4}-\beta_{60}-Y A G$ compatibility triangle in Fig. 1 . The amount of solid solution in each of the samples appears to increase after crystallization. It is apparent from Fig. 1 that the location of what was considered to be the original composition shifted during sintering. Since the $\beta$-phase-YAG tie lines do not contain the starting composition point, the location of the starting composition is changed during sintering. $\mathrm{SiO}$ gas evaporates from the samples, especially at higher sintering temperatures. This is apparent from the sintered sample weight losses. The weight losses for samples sintered at $1650^{\circ} \mathrm{C}$ were about $2 \%$, but for the samples sintered at $1750^{\circ} \mathrm{C}$, weight losses were $3 \%$, causing the apparent shift in starting composition. New tie lines are drawn to compensate for this shift. Tie lines connect the original $\beta$-phase lattice parameters to the approximate starting composition (on the $\beta$-phase-YAG tie line) and continue to the liquidus location, since the relative weight fractions of $\beta$-phase and liquid phase are known from the original heat treatments. Figure 2 shows a combined diagram with $1550^{\circ}, 1650^{\circ}$, and $1750^{\circ} \mathrm{C}$ isotherms. The approximated liquid phase regions are depicted in Fig. 3. The liquid region extends further into the compatibility triangle at $1750^{\circ} \mathrm{C}$. These results are consistent with those seen by Bonnell et al. ${ }^{14}$ The results differ, however, from those seen by Spacie et al. ${ }^{\rtimes}$ These researchers show the liquid phase extending from the YAG- $\mathrm{Si}_{3} \mathrm{~N}_{4}$ join at $1700^{\circ} \mathrm{C}$. This phenomenon is similar to what was observed prior to accounting for the shift in starting composition. Since weight losses occur in the sintered samples, shifts in the starting composition must be taken into account.

\section{Conclusion}

The solid-liquid equilibrium isotherms have been constructed for the system $\mathrm{Si}_{3} \mathrm{~N}_{4}-\mathrm{SiAlON}-\mathrm{YAG}$ at $1650^{\circ}$ and $1750^{\circ} \mathrm{C}$. The liquid phase extends from the $Y A G-\beta-S i A l O N$ join and increases with increasing temperature. Phase equilibrium and starting composition compensation are two necessary factors in determining these isotherms. The methods of using $\mathrm{X}$-ray diffraction for phase identification and scanning electron microscopy for volume fraction determinations have been effective in analyzing these solid-liquid reactions.

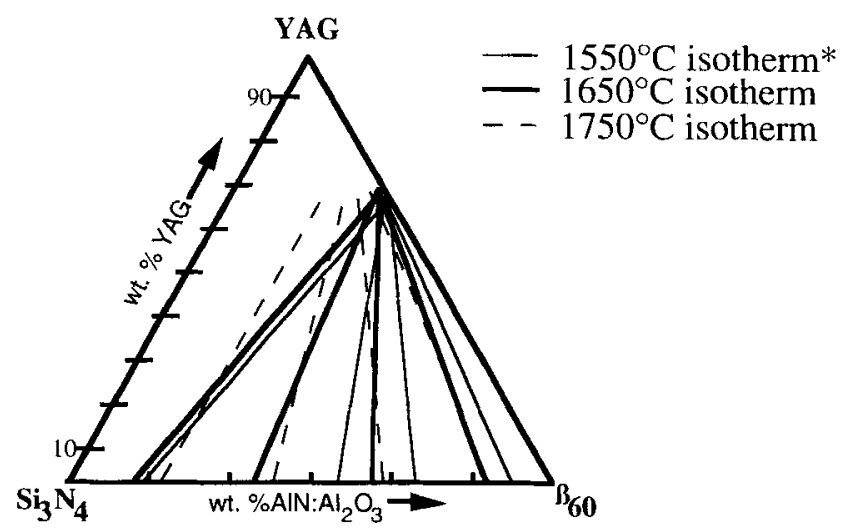

Fig. 2. New tie lines are drawn connecting the weight percent AlN: $\mathrm{Al}_{2} \mathrm{O}_{3}$ of the original $\beta$-phase to the approximate position of the starting composition on the $\mathrm{Si}_{3} \mathrm{~N}_{4}-\mathrm{YAG}$ tie line. The lengths of the tie lines were determined from the relative amounts of liquid and $\beta$-phase after heat treatments at $1650^{\circ}$ and $1750^{\circ} \mathrm{C}$. ( ${ }^{*}$ Hohnke and Tien, ${ }^{7} \mathrm{p}$. 103.) 


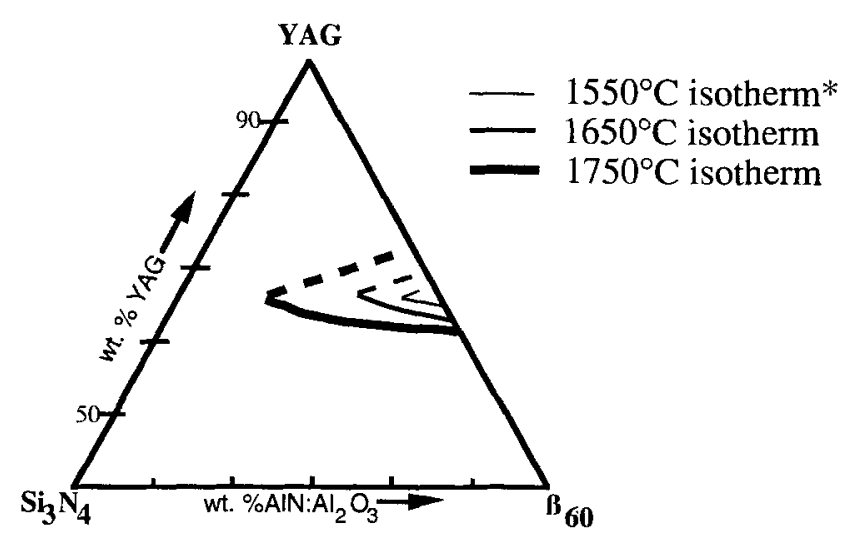

Fig. 3. Approximated liquid phase regions for $1550^{\circ}, 1650^{\circ}$, and $1750^{\circ} \mathrm{C}$. The continuous lines represent experimentally determined isotherms, and the dashed lines represent estimated upper bounds to the liquid phase region. (*Hohnke and Tien, ${ }^{7}$ p. 103.)

\section{References}

${ }^{1} \mathrm{~K}$. H. Jack and W. J. Wilson, "Ceramics Based on the Si-Al-N-O and Related Systems," Nature (London) Phys. Sci., 238 [80] 28-29 (1972).

${ }^{2}$ L. J. Gauckler, H. L. Lukas, and G. Petzow, "Contribution to the Phase Diagram $\mathrm{Si}_{3} \mathrm{~N}_{4}-\mathrm{AlN}_{-} \mathrm{Al}_{2} \mathrm{O}_{3}-\mathrm{SiO}_{2}$," J. Am. Ceram. Soc., 58 [7-8] 346-47 (1975).
${ }^{3}$ L. J. Gauckler and G. Petzow, "Representation of Multi-component Silicon Nitride Based Systems"; pp. 41-62 in Progress in Nitrogen Ceramics. Edited by F. Riley. Noordhoff, Leyden, Netherlands, 1977.

${ }^{4} \mathrm{~L}$. J. Gauckler, H. Hohnke, and T. Y. Tien, "The System $\mathrm{Si}_{3} \mathrm{~N}_{4}-\mathrm{SiO}_{2}-\mathrm{Y}_{2} \mathrm{O}_{3}$," J. Am. Ceram. Soc., 63 [1-2] 35-37 (1980).

5. K. Naik, L. J. Gauckler, and T. Y. Tien, "Solid-Liquid Equilibria in the System $\mathrm{Si}_{3} \mathrm{~N}_{4}-\mathrm{AlN}-\mathrm{SiO}_{2}-\mathrm{Al}_{2} \mathrm{O}_{3}$, J. Am. Ceram. SoC, 61 [7-8] 332-35 (1978).

${ }^{6} \mathrm{~W}$. Y. Sun, T. Y. Tien, and T. S. Yen, "Subsolidus Phase Relationships in Part of the System $\mathrm{S}, \mathrm{Al}, \mathrm{Y} / \mathrm{N}, \mathrm{O}$ : The System $\mathrm{Si}_{3} \mathrm{~N}_{4}-\mathrm{AlN}-\mathrm{YN}-\mathrm{Al}_{2} \mathrm{O}_{3}-\mathrm{Y}_{2} \mathrm{O}_{3}$," J. Am. Ceram. Soc., 74 [11] 2753-58 (1991).

${ }^{7} \mathrm{H}$. Hohnke and T. Y. Tien, "Solid-Liquid Reaction in Part of the System Si,Y/N,O"; pp. 101-10 in Progress in Nitrogen Ceramics. Edited by F. L. Riley. Martinus Nijhoff, The Hague, Netherlands, 1983.

${ }^{\gamma}$ C. J. Spacie, N. S. Jameel, and D. P. Thompson, "The Fabrication of TwoPhase $\beta$-SiAION-YAG Ceramics"; see Ref. 7, pp. 343-49.

"M. H. Mueller and L. Heaton, "Determination of Lattice Parameter with the Aid of a Computer," Final Report of Metallurgy Program 4.1.8, Report No. ANL-5975; pp. 67-77. Argonne National Laboratory, Argonne, IL, 1959.

1"L. J. Gauckler, J. Weiss, T. Y. Tien, and G. Petzow, "Insolubility of Mg in $\beta-\mathrm{Si}_{3} \mathrm{~N}_{4}$ in the System Al,Mg,Si/N,O," J. Am. Ceram. Soc., 61 [9-10] 397-98 (1978).

"E. Underwond, Quantitative Stereology. Addison-Wesley, Reading, MA, 1970.

'D. Messier, "Preparation Crystallization of Si-Y-Al-O-N Glasses," Ceram. Eng. Sci. Proc., 3 [9-10] 565-76 (1982).

${ }^{1} \mathrm{~L}$. J. Gauckler, "Phase Equilibria Studies in the System Si,Al/N,O and $\mathrm{Si}, \mathrm{Al}, \mathrm{Be} / \mathrm{N}, \mathrm{O}$ "; Sc.D. Thesis. University of Stuttgart, Federal Republic of Germany, 1976.

${ }^{14}$ D. A. Bonnell, M. Ruhle, and T. Y. Tien, "Redistribution of Aluminum Ions during Processing of SiAlON Ceramics," J. Am. Ceram. Soc., 69 [8] 623-27 (1986). 